end of the extractor, so as to get all the juice to pour out from the slot in the under surface of the instrument. If the screw is tightened up too much the pulped meat will come through with the juice. If, on the other hand, the screw is left too far out the meat is not compressed sufficiently and the quantity of the juice is reduced. A little experience enables the operator to strike the right point. Two pounds of beef should give about two wineglassfuls of juice. Collect the juice and separately collect the crushed meat. Strain the juice through muslin and leave it aside till wanted. Next take the crushed meat, pour on it a pint and a half of cold water, and let it stand for two hours. Then simmer very slowly for two hours, set it aside, and when cold strain off the clear fluid.

For use, heat this clear beef-tea and when it is just fit to drink-say at a temperature of $105^{\circ}$ to $115^{\circ} \mathrm{F}$., just comfortable to swallow-add to it the strained raw meat juice. Flavour with salt and serve. Observe particularly that the meat juice must be added when the beef-tea is so far cooled that the patient can drink it. If the beef-tea is hotter (say $160^{\circ} \mathrm{F}$. or over) the albumen of the meat juice coagulates and its nutritive value is deteriorated. Beef-tea thus prepared is very palatable and can be given to patients without their knowing that they are taking raw meat juicea very important matter as many persons would not touch raw meat if they knew it. For those who like a full-flavoured beef-tea half a teaspoonful of "Maggi's essence aux fines herbes" may be added. This excellent condiment can be had from Cosenza and Co., 95, Wigmore-street, London, W. This beef-tea may be rendered still more nutritious by the addition of some farinaceous element, as follows. Before the addition of the raw meat juice bring the clear beef-tea to boiling point and then dust in a teaspoonful or so of Groult's tapioca and boil for ten minutes or until the tapioca is transparent; or add to it a teaspoonful of fine arrowroot or cornflour, blended in a tablespoonful of water, boiling then for ten minutes. Now let the beef-tea cool so as to be fit to drink, then add the salt or flavouring essence and the strained raw meat juice. I have never yet met a patient who did not like this "special beef-tea" and take it willingly.

I am, Sirs, yours faithfully,

Dublin, February, 1903 . Francis R. Cruise, M.D. Dub.

\section{URANIUM SALTS IN CANCER: A SUGGESTION.}

\section{To the Editors of THE LANCET.}

SIRs,-Any drug that offers the faintest hope in the treatment of cancer seems worthy of a trial. Now, since cancer seems to begin as an overgrowth of the cell, anything that tends to modify this might do good. Uranium nitrate when given to animals causes ulceration at the pyloric end of the stomach, but when given to man does not do so, though it doubtless tends to. It might be worth an extended trial in certain cases of cancer at the pyloric end of the stomach and it would be interesting to know in what way the cells had been modified as shown by the microscope. The action of uranium is specific, since it acts in animals when the drug has not been introduced directly into the stomach. From this one might reason that it would modify an overgrowth of the cell in any part of the body, and that a sterilised injection into a growth, be it cancer or fibroid, might do some good. The claims of a country practice do not allow me to work out all this, and the material is not available. My only experience is in the case of cancer of the larynx, where a 1 per cent. spray had a marked effect in checking hæmorrhage and in lengthen. ing the interval between each attack. I have put the idea before some of my medical friends in Liverpool and they think it worth a trial; but as I cannot find any record of its use in this way, I venture to bring it forward. Dr. S. West has used it with some promise in diabetes and has given it in doses of from one-eighth of a grain up to 20 grains three times a day. The late Dr. Drysdale recorded a cure in ulcer of the stomach. The action of uranium in diabetes has been thought to be due to its helping to eliminate uric acid, and this brings another view of cancer before us. It seems to be established that cancer is more common in the well-nourished, and it may be that the overgrowth of the cell is due to excess of nutrition over combustion and excretion, thus causing products akin to uric acid to irritate and so cause an increased growth. If this is so, then probably the best drug would be salicylate of uranium when the chemist can make it. For experience teaches me that there is a good deal in Dr. Haig's opinion of the value of the salicylates in chronic gouty conditions. Possibly they act by increasing combustion and oxidising uric acid into urea, or in fevers by oxidising the specific virus to render it inert. No one, of course, expects a drug to cure cancer, but it might be possible to modify it in the way that mercury modifies syphilis. When mounted on a theory one is apt to ride it to absurdity, but it may be that such growths as post-nasal adenoids which are far more common in the children of the rich and presumably well-nourished than in the children of the poor, may be due to excess of nutrition over combustion either in the mother or child or both. The theory occurred to me before I had heard of uranium and as the drug seemed to offer some chance of success I venture to put it forward in the hope that some may think it worthy of a trial.

I am, Sirs, yours faithfully,

Formby, Feb, 4th, 1903 Arthur C. Wilson, M.B., Ch.B. Vict.

\section{BRISTOL AND THE NON-VENTILATION OP SEWERS.}

To the Editors of THE LANCET.

Sirs,-Your Special Commissioner's report on the above subject, published in THE LANCET of Jan. 17th, p. 202, shows that notwithstanding the long stretch of daily exposed mud or river deposit and its system of non-ventilation of sewers Bristol has always had a better health record than towns and districts professing to have a system. This, one would think, should have called forth remarks either from the engineers or the medical officers of health connected with towns and districts whose records are not so good as Bristol, and also of towns and districts, including the London districts, whose records have a better average.

There cannot be much doubt but that the major portion of sewered towns and districts suffer from systems which are most defective in that the ventilators of the lower levtls poison the atmosphere of the higher levels, and the leaky sewers of the higher levels poison the atmosphere of the lower levels via air currents underground, including the channels into the residences formed around drains, water- and gas-pipes, \&c. the circulation set up causing a more virulent outbreak of illness in the high portions of the town than in the lower, the higher portion being supposed to be the most healthy and containing as a rule the better class of residents. Trusting that even now the question (which is a serious and most important one) may have attention from those able thoroughly to discuss it. Feb. 3rd, 1903. I am, Sirs, yours faithfully,

\section{THE DANGERS OF CALCIUM CARBIDE.}

\section{To the Editors of THE LANCE'T.}

SIRS,-Calcium carbide is a substance which has come into considerable use within the last few years, as it has the unique property of developing a gas which can be used as an illuminant when water is poured on it. Not only is it used for lighting houses, \&c., as a source of acetylene gas, but it is extensively adopted all over the country for bicycle lamps. This substance is already the subject of legi-lative enactments as to storage, \&c., on account of its inflummable and explosive character, but I beg to point out that it has been overlooked from the public health point of view and that persons who are compelled to handle it should be protected by provisions of law.

My attention was forcibly directed to this matter by a patient who presented himself for treatment for dyspnœa, bæmoptysis, headache, anirexia, and various neurasthenic symptoms, and who exhibited signs of patchy consolidation of the lungs, but who exhibited no rise of temperature or sign of tuberculous trouble. He was a lad, aged 14 year, but quite stunted for that age, and on questioning him to elucidate some cause for his symptoms I discovered that his occupation was to fill tins with calcium carbide and he gave a vivid and graphic description of the histing sound which was produced when a particle of the substance happened to be inhaled through the nose or get down the throat, as well as the irritant cough and difficulty of breathing which troubled him whilst at work and the comparative ease he at once enjoyed when he got into the air. From the violent 
chemical action which takes place when calcium carbide comes in contact with any mucous surface $I$ suggest that some protection for workers with it is imperative. I am, Sirs, yours faithfully

Dublin, Feb. 5th, 1902 J. C. MoWalter, M.A., D.P.H.

\section{THE MIDWIVES ACT.}

To the Editors of THE LANCET.

SIRS,-The passing of the Midwives Act of 1902 devolves a grave responsibility on the nation in order that, as the untrained midwife vanishes, the poor who either cannot, or will not, be attended by medical men may not be left without necessary assistance. A clergyman writes to me, "We have no maternity charity or help of any sort towards doctor or nurse ;...... it is sad to see the suffering from neglect and ignorance and feel utterly at the mercy of these untrained women. How the Act will affect us I cannot guess if it stops the present dangerous system and gives us nothing in its place. I am not sure that it will be an advantage. I am sure our poor women won't consider it so. They can't afford to engage a trained monthly nurse, especially from a distance, or to send for a doctor."

Now it is to help these remote scattered parishes, as well also as the crowded provincial towns where these untrained women are so numerous and prosperous that $I$ am anxious to gain the sympathy of those able to help. First of all, I would enlist the coopperation of the local medical man who feels that the village midwife working under proper supervision would be a help rather than a hindrance to his workof the busy and often overworked family practitioner who recognises the fact that such women will relieve the pressure by taking those cases that use up his most valuable time and pay so little, if at all, and whom he may trust to send for him in good time when surgical skill is required. Then I would, where nursing associations exist or could be started, have one or two midwives attached and thus make use of existing organisations where possible. 1 have done this in my own case; the woman prepays an extra fee of from $5 s$. to $10 \mathrm{~s}$., which is returned to her if the medical man is not required. If he is sent for the association guarantees the payment

In very sparsely populated districts one or two might join together to provide a midwife, and the midwife might be encouraged to combine with her work some occupation not detrimental to her calling. In towns the work would become quickly self-paying, and I feel that a very moderate outlay would start a sound, substantial work. I cordially invite those interested, and especially medical men who approve of this scheme, to communicate with me, and I wonld ask others to help me with funds to make a good beginning.

I am, Sirs, yours faithfully,

JOSEPHINE JOHNSTONE.

Bignor Park, Pulborough, Feb. 7th, 1903.

\section{THE SURGICAL TREATMENT OF RHEUMATIC FEVER.}

To the Editors of THE LANCET.

SiRS,-From a long experience in South China, I can fully confirm the statements made by Dr. A. Haig in his letter under the above heading in THE LANCET of Feb. 7th, p. 398. Arthritic pains of all kinds are quickly relieved by the salicylates during the cool season, but much harm may follow if given when the thermometer stands above $80^{\circ} \mathrm{F}$.

I am, Sirs, yours faithfully, EDWARD HORDER, F.R.C.S. Edin.

Limpsfield, Feb. 9th, 1903.

\section{"TIS FORTY YEARS SINCE."}

\section{To the Editor's of THE LANCET.}

SiRS,-Having had occasion to refer to the lists of the London hospital staffs of 40 years ago as given in the Students' Number of THE LANCET of Sept. 20th, 1862, I think that it may interest your readers if I give a brief summary as to the survivorship of these gentlemen. Of course all who held office in 1862 have retired from active hospital work, as life appointments have long ceased to exist, and I shall only mention those still living.

At St. Bartholomew's Mr. Luther Holden, then assistant surgeon, is the sole survivor of the hospital staff, and Sir Thomas Smith, K.C.V.O., then demonstrator, of the teaching staff. At Charing Cross Mr. R. Barwell, then assistant surgeon, alone survives. At St. George's Sir Henry Pitman and Dr. J. W. Ogle, who were physician and assistant physician, Mr. Holmes, assistant surgeon, and Dr. W. Ogle, lecturer on physiology, survive. At Guy's Sir S. Wilks and Dr. F. W. Pavy, assistant physicians, Mr. J. Birkett, surgeon, and Mr. T. Bryant, assistant surgeon, remain. At King's College Dr. L. S. Beale, physician, Dr. A. B. Duffin, Dr. E. Thompson, and Dr. E. Liveing, assistant physicians, and Mr. Spencer Watson, assistant surgeon, remain. At the London Dr. R. Barnes, obstetric physician, and Mr. J. Hutchinson, Mr. J. Couper, and Mr. L. S. Little, assistant surgeons, survive. At St. Mary's Sir E. H. Sieveking, physician, with Sir W. H. Broadbent (physiology), and Mr. A. H. Norton, demonstrator, are the survivors. At the Middlesex Mr. Mitchell Henry and Mr. T. W. Nunn, assistant surgeons, and Dr. R. Liveing, demonstrator, survive. At the Royal Free Mr. Thomas $H$ Wakley and Mr. F. J. Gant, surgeons, and Mr. Hasler Harris, dental surgeon, remain. At St. Thomas's Dr. E. Clapton, assistant physician, Dr. H. Gervis, assistant accoucheur, Sir John Simon, K.C.B., surgeon, and Mr. Sydney Jones, assistant surgeon, survive. At University Sir Alfred B. Garrod, physician, and Sir H. Thompson, assistant surgeon, with Professor Williamson (chemistry), and Professor Oliver (botany) remain. At Westminster Dr. P. W. Latham, assistant physician, and Mr. H. Power and Mr. C. Heath, assistant surgeons, and Dr. Dupré (chemistry) survive.

I am, Sirs, yours obediently,

Historicus.

\section{NOTES FROM INDIA \\ (From oUR SPecial CORRespondent.)}

The Plague Epidemic.

THE mortality from plague throughout India is advancing by leaps and bounds. This week the total has risen to 19,224. The details published are: Bombay Presidency, 8962 deaths; the Punjab, 2442 ; the United Provinces, 2291 ; Bengal, 2124; the Central Provinces, 605; the Madras Presidency, 683 ; the Mysore State, 806 ; Bombay City, 443; and Calcutta, 37. In Poona the disease is raging very virulently; rearly 100 deaths are occurring daily, the normal death-rate of the city being 12 . In Calcutta a fresh outbreak has started and the figures are running up rapidly. This year the general development of plague is more widespread and involves a larger population than at any previous period. The Government has been compelled to abandon the system of inspection for plague on the railways in the United Provinces as hopeless. This inspection is credited with having postponed the invasion of certain areas, but when the disease has once attacked a province precautions on the railways are of no further avail.

Jan. 24th.

Presentations to Medical Practitioners. - At an "At Home" held at the Bath Saloon, Truro, on Feb. 5th, the Mayor of Truro, on behalf of the subscribers, presented Mr. Frederick Harold Carlyon, M. D., C.M. Edin., with an illuminated address and a cheque for $£ 55$ as a mark of respect and esteem on the occasion of his leaving for Johannesburg. The Mayoress presented Mrs. Carlyon with a diamond and sapphire bracelet.-Mr. Michael Halpenny, L.R.C.P., L.R.C.S. Edin., L.F.P.S. Glasg., has recently been presented with a gold semi-hunter keyless watch and a purse containing a sum of money by the inhabitants of Gilfach Goch. Mr. Halpenny recently left Gilfach Goch to practise in Ireland - At De Keyser's Royal Hotel, Thames-embankment, London, E.C., on Feb. 4tb, Mr. Theophilus Hoskin, J.P., L. R C.P. Lond., M.R.C.S. Eng., was presented by the Master of the Worshipful Company of Makers of Flaying Cards with a silver salver bearing the following inscription :"Presented to Dr. Theophilus Hoskin, J.P., by his colleagues on the Court of Assistants of the Worshipful Company of Makers of Playing Cards, in commemoration of his services to the Company as Master, 1901-1902." 